\title{
The Impact of Governance Indicators on Corruption in Arab Countries
}

\author{
Hayder Abbas Drebee ${ }^{1}$, Nor Azam Abdul Razak², and Razzaq Thiab Shaybth ${ }^{3}$
}

ABSTRACT

\begin{abstract}
This study aims to measure the impact of governance indicators on corruption in Arab countries during the period 2005-2016. Several techniques including co-integration, forecasting variance error decomposition, and impulse response function are employed. The results indicate that corruption is influenced by political stability, voice and accountability, and regulatory quality in both the short and long runs. The relative contribution of the change in regulatory quality to the change in corruption is weak, implying that there are weaknesses in laws, regulations and transparent legislation that determine the relationship between the state and the society and guarantee the integrity and rights of individuals. Therefore, fighting corruption needs to be an integral part of a comprehensive institutional and organizational reform strategy. This study is an important incentive for governments and global development organizations to improve governance performance to combat corruption. These governments may need external assistance that could be offered by the international development organizations to improve their indicators of good governance of corruption curb if Arab governments are not prepared to improve citizens' participation in this field.
\end{abstract}

KEY WORDS: Corruption, Political Stability, Voice and Accountability, Regulatory Quality, Good Governance.

JEL Classification: C01, C4.

University of Al-Qadisiyah, Iraq

University Utara Malaysia, Malaysia

${ }^{3}$ Al-Muthanna University, Iraq

\section{Introduction}

Corruption is an old-age phenomenon. In the context of economic development, a couple of perspectives could be distinguished. On the one hand, corruption has a negative impact on economic development because it hinders economic efficiency by imposing additional tax-like costs to entrepreneurs, creating barriers to businesses, increasing uncertainty about investment decisions, reducing foreign capital flows (especially foreign direct investment), and resulting in a misallocation of resources and poor distribution

Correspondence concerning this article should be addressed to: Hayder Abbas Drebee, University of Al-Qadisiyah, Iraq. E-mail: hayder.drebee@qu.edu.iq of public expenditure. Moreover, corruption increases the provision of public expenditure and decreases private expenditure, and health care education expenditure (Tanzi, 1998). On the other hand, corruption has a positive effect on economic development because it increases economic efficiency by reducing the costs of business delay (Elliot, 1997). This is true especially in countries where administrative bureaucracy prevails.

Interest in corruption studies has escalated owing to its negative social and economic effects. Given the seriousness of this phenomenon, it is necessary to formulate viable strategies to ensure that the ill effects of corruption are effectively contained. These efforts are not limited to developed countries, but also to developing countries that are more likely to suffer 
from this phenomenon. From this perspective, it is necessary to formulate policies to combat this phenomenon and thus achieve sustainable development. One of the most important current trends is to adopt transparent and accountable governance standards as a mechanism to create a stable business environment conducive to economic development.

The concept of good governance began in the early 1990s, coinciding with the fall of the Berlin Wall and the collapse of the Soviet Union (Weiss, 2000). Since then, a lot of research has been conducted on this topic, which has become an important concept in international development discussions and is used to explain why some countries with enormous resources are struggling for economic and political development. Yet until today, there is no consensus among researchers and development institutions on a clear definition of good governance. Grindle (2007) presented a list of definitions for "governance" and "good governance". Overall, good governance can be linked to the rule of law, transparency, efficient public service, accountability and the ability of citizens to express their points of view. According to the World Bank, the term governance refers to "rule by the rulers" under some defined laws, processes and vivid authority. As for the United Nations Development Program (UNDP), governance is a mechanism to administer the economic, political and administrative affairs of a country. Recently, the concept of good governance has received worldwide attention and is used as a major indicator of the overall health of a country. According to Besancon (2003), good governance is a result of effective performance and high administrative efficiency in the state mechanism.

The Corruption Perception Index (2016), published by the International Transparency Organization, reflects the perception of public and political corruption. This index, which monitors 176 countries, of which 20 are Arab countries, shows that more than two-thirds of these countries have achieved a rate below the middle of this scale, which ranges from 0 (very clean) to 10 (highly corrupt). The global rate average of corruption reaches 4.3 indicating that corruption is a worldwide phenomenon. When it comes to Arab countries, the results show that the United Arab Emirates was ranked 24th in the world and the first in the Arab world by gaining 6.1 points, despite having 7 points in 2015 and 2014. It was followed by Qatar, which was ranked second in the Arab world and 31st in the world. Most of the Arab countries were ranked at the bottom of this index (high corruption) such as Somalia, which was ranked last (with 1.4 points). South Sudan and Syria were ranked 175th and 173rd, respectively. Yemen, Sudan, and Libya were ranked 170th. According to this indicator, Arab countries have occupied low ranks, which raises questions about their seriousness in the fight against corruption.

It can be inferred from the above statistics that the Arab countries lack proper mechanisms through which institutional work is organized, and they fail to achieve the principles of good governance. Corruption has become the biggest obstacle to the development process in the Arab countries and the cause of the problems and crises that the world is having in recent years. Most studies have focused on the impact of corruption on economic development. Studies such as Brunetti, Kisunko and Weder (1998), Leite and Weidmann (1999), and Poirson (1998) indicated a positive influence of corruption on economic development, while Kanak \& Kfeir (1995) and Tanzi and Davoodi (1997) presented strong evidence of the negative impact of corruption on economic development. For example, Muthammad (2017) studied the effect of political stability, government effectiveness and corruption control on stock markets in South Asia, and Kaufmann and Kraay (2002) showed that the higher the level of governance, the higher the per capita income. However, Grindle (2004) argued that the concept of governance cannot be directly linked to development since the basic agenda of governance is to combat corruption and reduce poverty and other factors that constitute an obstacle to the path of economic development.

In light of this background, the objective of this study is to investigate the impact of governance indices (in particular, political stability, the absence of violence, regulatory quality, and voice and accountability) on corruption in the Arab countries. The significance of evidence (or lack of it) of the impact of a particular government index on corruption can be used as a basis to prioritize the government's tasks.

The rest of this study consists of four parts. The second part reviews a series of previous studies on the 
impact of governance on economic development and corruption. The third part presents data, statistical methods, and analysis of results. Finally, the fourth part four provides a summary of the findings and recommendations of the study.

\section{Literature Review}

Most studies in this area are confined to single countries rather than regions. For instance, Choi (2007) evaluated the causal relationships between governance and corruption in Japan. His study found that corruption diminishes public trust in governments and aids maladministration. To enhance governance and reduce corruption in Japan, the study recommended diversity management and citizen participation. According to Ngo (2008), the link between governance and corruption in China is tangled with economic management, and is used by government agents in a corrupt way because they are agents to collect additional profits through bribery in various areas such as construction, property, medical supplies, government procurement and exploration of natural resources. A study by Gao (2004) stated that South Africa's complex political design is a major factor contributing to the emergence of corruption, which had a negative impact on stability and confidence, which have affected the values and principles of democracy spirit.

Nonetheless, there are a few studies which cover more than single countries. For example, based on the data from 150 developing countries with 72,000 companies, Gander (2011) developed a simple model for the company's decision, which is based on uncertainty about the success of bribing a government official. According to this model, political instability and the governance system of developing countries are major factors in fueling corruption. Analyzing African politics from the point of view of corruption and governance, Zeftel (1998) presented that the governance agenda on the continent addressed corruption as if it were the cause of democratic and developmental problems and not as a result. The more the transparency and accountability, the less the scope of bribery (Buehn \& Schneider, 2009). Aidt, Dutta and Sena (2008) investigated the impact of political accountability on the development of corruption and found out that the ability to hold political leaders accountable may influence corruption, which affects economic development. Wagner and Schneider (2005) expanded his understanding of this issue to compare the relationship between governance and economic well-being and economic prosperity. They found that a broader understanding of good governance is not exclusively the state's responsibility but also the citizens' attitudes toward the state and law in a kind of cooperation between the state and citizens.

Campos and Nugent (2003) concluded that the rule of law and political stability are necessary to ensure clean systems and a strong legal support to remove any obstacles in attracting investment, which is one of the main factors contributing to economic development. Daniel Treisman (2000) noted that successful democracy through monitoring and balance of power limits the government authority and increases its control over corruption. By contrast, ethnic diversity, which can lead to nepotism and complicity, has a positive relationship with corruption. Ethnic diversity may lead to conflicts that could lead to political instability and protracted civil war (Montalvo and Reynal-Querol, 2005). Mauro (1995) found that ethnic diversity leads to a lower level of investment and has a negative relation to economic development. In their study, Hall and O'Neil (2002) concluded that the freedom of press and democracy reinforce each other, especially when press freedom and a strong civil society are combined. Brunetti and Weder (1999) argued that press freedom is associated with a low public corruption of the press, enabling the media to publish balanced news about the government, including news of committed corruption by government officials, thereby strengthening the accountability mechanism of the public, which promotes the monitoring of corruption.

For the Arab countries, there are few studies on the corruption which focused on the relationship between corruption and economic growth. One such study is Ahmed and Asmaa (2016), which tried to focus on how corruption could have affected economic growth in 15 Arab countries during the period 1998-2009. Another study is the one conducted by Kamel Touati (2014). Using a panel of countries over the period 2005-2010, he showed that there exists a significant relationship between economic development and corruption. 


\section{Data Analysis and Discussion}

Most corrupt activities are classified as illegal, so they are difficult to be measured. Moreover, the objective measure of corruption (such as the number of individuals convicted of a corrupt act) has been criticized for many reasons. For example, Lambsdorff (1999, 2006) stated that the high level of conviction in Singapore and Hong Kong does not mean that corruption is high in these countries; rather it indicates that judicial and anti-corruption bodies are effective in detecting and prosecuting corrupt individuals. In view of the scarcity of the objective measure, indicators of perception of corruption are mostly used (Gyimah-Brempong, 2002). To this end, the corruption perception index (CPI), which is published annually by an international body known as the Transparency International (TI), was used in many studies (Abu, Karim and Aziz, 2015; Swaleheen, 2007).

CPI is a composite index, drawing on corruptionrelated data from expert and business surveys carried out by a variety of independent and reputable institutions. CPI ranges from 0 (very corrupt) to 10 (very clean). CPI ranks countries in terms of the degree to which corruption is perceived to exist among public officials and politicians.

World Bank's Worldwide Governance Indicators (WGI) reports aggregate and individual governance indicators for 212 countries across six dimensions of governance: voice and accountability, political stability and the absence of violence, government effectiveness, regulatory quality, rule of law, and control of corruption. The aggregate indicators combine the views of a large number of enterprise, citizen and expert survey respondents in industrial and developing countries. The individual data sources underlying the aggregate indicators are drawn from a diverse variety of survey institutes, think tanks, nongovernmental organizations (NGOs), and international organizations. In theory, all governance indicators are of particular importance, especially in developing countries where there are already several governance problems. Depending on the data availability, the following indicators are emphasized:

1. Voice and Accountability (VA). It refers to the ability of citizens of a country ( including the military) to participate in the election of their governments, as well as freedom of expression, freedom of association and freedom of the media, including the military in politics and democratic accountability.

2. Political Stability and the Absence of Violence (PS). It refers to the possibility of destabilizing the government by unconstitutional means or through violence, including terrorism, internal conflict, external conflict and ethnic tensions.

3. Regulatory Quality (RQ). It refers to the ability of a government to provide policies and regulations that determine the relationship between the state and the society and guarantee the integrity and rights of the people regardless of their colors and orientations and the application of laws to ensure the establishment of rules of justice among members of society.

The governance indices used in this study were drawn from the PRS Group and the World Governance Indicators for the period 2005-2016, while the corruption data were obtained from TI. The study covered 14 Arab countries (Kuwait, Sudan, Tunisia, Morocco, Egypt, Algeria, Yemen, United Arab Emirates, Saudi Arabia, Qatar, Oman, Lebanon, Iraq, and Bahrain) and adopted co-integration, impulse response function (IRF) and forecast error variance decomposition (FEVD), which were estimated by the panel Vector Error Correction Model (PVECM).

The Pearson correlation coefficient is used to measure the strength and direction of the relationship between any two independent variables. Table $1 \mathrm{dem}-$ onstrates that there is a strong positive relationship below at the $1 \%$ significance level among the study variables. The highest correlation value between corruption and political stability is 0.84 . Therefore, it does not exceed the value of 0.9 , suggesting that there is no severe multicollinearity problem between any two independent variables (Hair Black, Babin, Anderson, \& Tatham, 2006).

Table 2 shows that the average corruption in the Arab countries is 3.877. While the lowest value is 1.1, the highest value is 7.7. The average value of political stability is 0.697 ; the regulatory quality average is 0.713 , while the average value of voice and accountability is 0.517 .

\subsection{Panel Unit Root Test}

Prior to examining the relationship among variables, unit root tests are performed to verify the stationarity of the variables. The regression results would be 
Table 1. Correlation Matrix

\begin{tabular}{|c|c|c|c|c|}
\hline & LnCORR & LnPS & LnRQ & LnVA \\
\hline LnCORR & 1.000 & & & \\
\hline LnPS & $\begin{array}{c}0.840 * * * \\
(0.000)\end{array}$ & 1.000 & & \\
\hline LnRQ & $\begin{array}{c}0.714^{* * *} \\
(0.000)\end{array}$ & $\begin{array}{c}0.647^{* * *} \\
(0.000)\end{array}$ & 1.000 & \\
\hline LnVA & $\begin{array}{c}0.591^{* * *} \\
(0.000)\end{array}$ & $\begin{array}{c}0.577^{* * *} \\
(0.000)\end{array}$ & $\begin{array}{c}0.447^{* * *} \\
(0.000)\end{array}$ & 1.000 \\
\hline
\end{tabular}

Note: ${ }^{* * *}$ indicates a rejection of the null hypothesis at the $1 \%$ significance level

Table 2. Summary of Variable Description

\begin{tabular}{|c|c|c|c|c|}
\hline & CORR & PS & RQ & VA \\
\hline Mean & 3.877 & 0.697 & 0.713 & 0.517 \\
\hline Median & 3.7 & 0.708 & 0.689 & 0.542 \\
\hline Maximum & 7.7 & 0.890 & 0.955 & 0.750 \\
\hline Minimum & 1.1 & 0.354 & 0.318 & 0.167 \\
\hline Std. Dev. & 1.6 & 0.130 & 0.162 & 0.150 \\
\hline Skewness & 2.83 & -0.557 & -0.065 & -0.915 \\
\hline Kurtosis & 2.325 & 2.512 & 2.055 & 3.188 \\
\hline
\end{tabular}

spurious and statistical analysis would be problematic if the variables are non-stationary (Granger \& Newbold, 1974; Phillips, 1986).

Prior to performing the unit root test, lag order selection criteria are employed to choose the appropriate lag length. Table 3 shows that, except for LR, the various criteria adopted (FPE, AIC, SC and HQ) indicate that the optimum lag criterion is 1.

The Fisher-Augmented Dickey-Fuller (FisherADF) and Fisher-Phillips Perron (Fisher-PP) tests are used to determine the presence of unit roots. Table 4 shows the results of the unit root tests at the levels and at the first differences at the significant level of $5 \%$ and $10 \%$. The results indicate that 
all variables exhibit unit roots at the level, and they become stationary after taking the first difference. This is consistent with the common finding that many macroeconomic variables are non-stationary at their levels, but become stationary after taking the first differences (Nelson \& Plosser, 1982).

\subsection{Panel Co-integration Test}

Given that the series are non-stationary at their levels but become stationary at their first differences, that is, I (1), a long-term equilibrium relationship among them would be tested. If the series are integrated, this means that the estimated relationship between these variables will be free from spuriousness. Moreover, the existence of co-integration among these variables indicates that causation exists in at least one direction between these variables (Granger, 1986). To achieve this objective, Pedroni residual co-integration test will be used (Pedroni, 1997 \& 1999). The results, as shown in Table 5, indicate a co-integration between corruption and each of the governance indicators under study (political stability, voice and accountability, and regulatory quality). In other words, a long-run relationship between corruption and each governance indicator exists.

\subsection{Panel Vector Error Correction Model (VECM)}

If all variables are non-stationary at their levels, stationary at their first differences and cointegrated, then it is appropriate to employ PVECM to test the causal relationship between variables in both the short and long runs. In PVECM, all variables are treated as a dependent variable in different forms. For this reason, the number of equations in VECM is equal to the number of variables. The PVECM equation can be written as follows:

$$
\begin{aligned}
& \Delta L n C O R R_{i t}=\alpha_{0}+\sum_{j=1}^{J} \alpha_{1} \Delta L n P O L_{i t-j}+\sum_{i=1}^{J} \alpha_{2} \Delta L n R Q_{i t-j} \\
& +\sum_{i=1}^{J} \alpha_{3} \Delta L n V A_{i t-j}+\sum_{i=1}^{J} \alpha_{4} \Delta L n C O R_{i t-j}+\phi_{1} E C T_{t-1}+\varepsilon_{1 i t} \text { (1) } \\
& \Delta L n P O L_{i t}=\beta_{0}+\sum_{j=1}^{J} \beta_{1} \Delta L n C O R R_{i t-j}+\sum_{i=1}^{J} \beta_{2} \Delta L n R Q_{i t-j} \\
& +\sum_{i=1}^{J} \beta_{3} \Delta L n V A_{i t-j}+\sum_{i=1}^{J} \beta_{4} \Delta L n P O L_{i t-j}+\phi_{2} E C T_{t-1}+\varepsilon_{2 i t}(2)
\end{aligned}
$$

$$
\begin{aligned}
& \Delta L n R Q_{i t}=\lambda_{0}+\sum_{j=1}^{J} \lambda_{1} \Delta L n C O R R_{i t-j}+\sum_{i=1}^{J} \lambda_{2} \Delta L n P O L_{i t-j} \\
& +\sum_{i=1}^{J} \lambda_{3} \Delta L n V A_{i t-j}+\sum_{i=1}^{J} \lambda_{4} \Delta L n R Q_{i t-j}+\phi_{3} E C T_{t-1}+\varepsilon_{3 i t}(3) \\
& \Delta L n V A_{i t}=\gamma_{0}+\sum_{j=1}^{J} \gamma_{1} \Delta L n C O R R_{i t-j}+\sum_{i=1}^{J} \gamma_{2} \Delta L n P O L_{i t-j} \\
& +\sum_{i=1}^{J} \gamma_{3} \Delta L n R Q_{i t-j}+\sum_{i=1}^{J} \gamma_{4} \Delta L n V A_{i t-j}+\phi_{4} E C T_{t-1}+\varepsilon_{4 i t}(4)
\end{aligned}
$$

where $\operatorname{Ln}$ is the log of the variables; $\Delta$ is the first difference; $\varepsilon$ is the residuals; $E C T_{t-1}$ is the one period lagged behind the error correction term.

After making sure that there is a long-term relationship between corruption and each governance indicator, the next step would be to study the dynamic relationship among the variables. Table 6 shows that the estimated coefficient of ECT is negative and significant, suggesting a long-run equilibrium relationship among the variables. The magnitude of the estimated coefficient implies that the speed of adjustment from the last year's disequilibrium in corruption is $6 \%$. IRF and VDC will be used to understand the dynamic relationship between corruption and each of governance indicator under study in the period beyond the study period.

\subsection{Impulse response function (IRF)}

IRF reflects how variable of interest response to a shock to the other variables in the system. Figure 1 presents the reaction of corruption to a sudden impulse of one standard deviation in corruption, political stability, voice and accountability and regulatory quality.

Figure 1 shows that any sudden impulse to the variables of the study at one standard deviation positively affects corruption. This means that the net effect of variables on corruption is positive. In other words, the positive effects of political stability, voice and accountability and regulatory quality on corruption are greater than the negative impact of these variables on corruption. As shown in Figure 1 , corruption is affected by political stability, voice and accountability and regulatory quality in the both the short and long runs, confirming that there is a long-run equilibrium relationship between the study variables, which were shown by the results of the co-integration as in Table 5. 
Table 3. VAR Lag Order Selection Criteria

\begin{tabular}{|c|c|c|c|c|c|c|}
\hline Lag & $\log \mathrm{L}$ & LR & FPE & AIC & SC & HQ \\
\hline 0 & 52.196 & NA & $4.97 e-06$ & -0.861 & -0.764 & -0.82 \\
\hline 1 & 561.976 & 974.042 & $7.36 \mathrm{e}-10^{*}$ & $-9.678^{*}$ & $-9.193^{*}$ & $-9.481^{*}$ \\
\hline 2 & 576.692 & 27.068 & $7.54 \mathrm{e}-10$ & -9.655 & -8.781 & -9.301 \\
\hline 3 & 589.542 & 22.716 & $8.00 \mathrm{e}-10$ & -9.598 & -8.337 & -9.087 \\
\hline 4 & 605.709 & $27.426^{*}$ & $8.02 \mathrm{e}-10$ & -9.601 & -7.951 & -8.932 \\
\hline
\end{tabular}

Response to Cholesky One S.D. Innovations
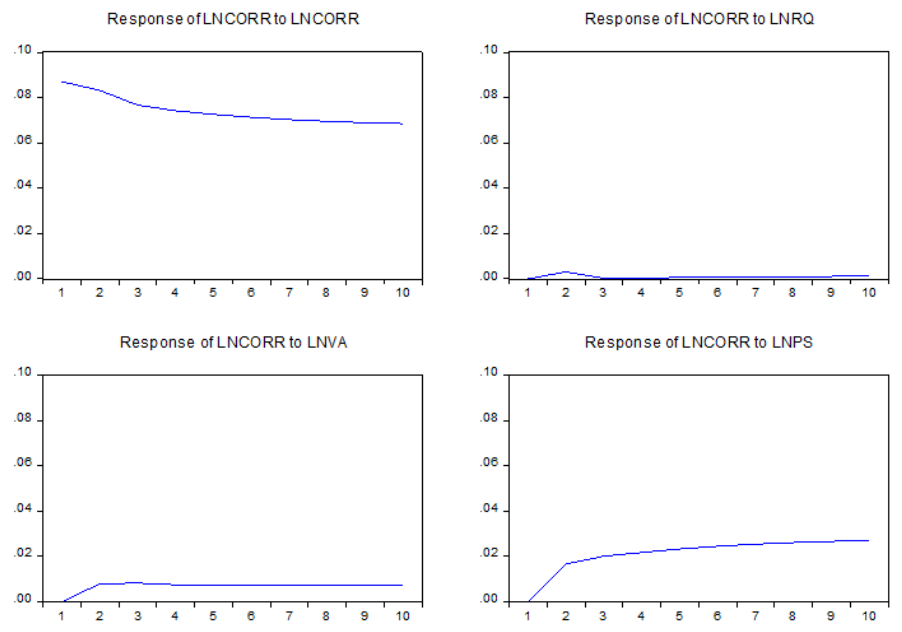

Figure 1. Response of LNCORR to Cholesky (d.f.adjusted) one S.D. Innovation. 
Table 4. Results of Panel Unit Root Test

\begin{tabular}{lcccc}
\hline Variables & \multicolumn{2}{c}{ Fisher -ADF } & \multicolumn{2}{c}{ Fisher-PP } \\
\cline { 2 - 5 } & Level & $\mathbf{1}^{\text {st }}$ diff. & Level & $\mathbf{1}^{\text {st }}$ diff. \\
\hline \multirow{2}{*}{ LnCORR } & & & & \\
& 37.050 & $100.216^{* *}$ & 34.531 & $105.727^{* *}$ \\
& $(0.118)$ & $(0.000)$ & $(0.183)$ & $(0.000)$ \\
LnPS & & & \\
& 16.601 & $51.813^{* *}$ & 23.273 & $126.289^{* *}$ \\
& $(0.956)$ & $(0.004)$ & $(0.719)$ & $(0.000)$ \\
LnRQ & & & 13.988 & $83.997^{* *}$ \\
& 16.164 & $40.455^{*}$ & $(0.973)$ & $(0.000)$ \\
LnVA & $(0.932)$ & $(0.060)$ & & \\
& 14.398 & $20.728^{*}$ & 19.045 & $41.664^{* *}$ \\
& $(0.703)$ & $(0.054)$ & $(0.389)$ & $(0.000)$ \\
\hline
\end{tabular}

Note: ${ }^{\star}$ and ${ }^{* *}$ indicates a rejection of the null hypothesis at $5 \%$ and $1 \%$ significance level, respectively

\subsection{Forecast Error Variance Decomposition Analysis (FEVD)}

In an attempt to understand the dynamic relationship among corruption, political stability, voice and accountability, and regulatory quality beyond the period 2005-2016, FEVD is conducted. This function is useful in ascertaining the amount of variation in a variable that is caused by its own shock and by shocks on other variables in the model. The results of FEVD of corruption to a one standard deviation shock in corruption, political stability, voice and accountability, and regulatory quality over 10 years' period are reported in Table 7 .

Overall, Table 7 shows that the estimated value of the relative importance of each variable (except regulatory quality) is statistically significant, where the magnitude is at least twice the standard error (Wheelar, 1999; Drebee, Azam, \& Razzaq, 2017). However, there is one exception: the impact of regulatory quality is negligible during the years of study. This indicates a weakness or lack of laws, regulations, and legislation that are transparent and conventional. The results of FEVD also demonstrate that shocks to corruption and political stability are more important than shocks to regulatory quality, and voice and accountability. For instance, political stability and voice accountability explain
$1.871 \%$ and $0.427 \%$, respectively, of the variations in the corruption, respectively, in the second year, whereas political stability, and voice and accountability account for $8.312 \%$, and $0.826 \%$, respectively, of the variations in corruption in the tenth year. In addition, the relative importance of the impulse of political stability, and voice and accountability is gradually increased from the first year to the tenth year. In particular, the relative importance of political stability, and voice and accountability increases from $1.871 \%$ and $0.427 \%$, respectively, in the first year to $5.136 \%$ and $0.726 \%$, respectively, in the fifth year and then increases to $8.312 \%$ and $0.826 \%$ respectively, in the tenth year.

\section{Conclusion}

This study examines the impact of governance indicators on corruption during the period 20052016 in selected Arab countries. To achieve this objective, co-integration, IRF, and FEVD, are employed. The results of the co-integration analysis indicate that a long-run equilibrium relationship is observed between corruption and each governance indicator under study (political stability, voice accountability and regulatory quality). The results of IRF demonstrate that a one standard deviation shock to political stability, voice and accountability 
Table 5. Pedroni Residual Co-integration Test Results

\section{Statistics \\ (within-dimension)}

$\begin{array}{lcccc} & \text { Statistic } & \text { Prob. } & \text { Statistic } & \text { Prob. } \\ \text { Panel v-Statistic } & -0.712 & 0.762 & -0.874 & 0.925 \\ \text { Panel rho-Statistic } & 1.555 & 0.940 & 1.256 & 0.896 \\ \text { Panel PP-Statistic } & -1.904^{* * *} & 0.029 & -2.124^{* * *} & 0.017 \\ \text { Panel ADF-Statistic } & -2.316^{* * *} & 0.000 & -2.396^{* * *} & 0.008\end{array}$

Statistics (between-dimension)

$\begin{array}{llc} & \text { Statistic } & \text { Prob. } \\ \text { Group rho-Statistic } & 2.805 & 0.998 \\ \text { Group PP-Statistic } & -2.568^{* * *} & 0.005 \\ \text { Group ADF-Statistic } & -3.183^{* * *} & 0.000\end{array}$

Note: ${ }^{* \star}$ indicates a rejection of the null hypothesis of no co-integration at the $1 \%$ significant level.

Table 6. VAR Lag Order Selection Criteria

\begin{tabular}{lccc}
\hline Variables & Coefficient & Std. Error & t-Statistic \\
\hline LnRQ & -0.052 & 0.118 & 0.659 \\
LnVA & 0.08 & 0.115 & 0.696 \\
LnPS & 0.169 & 0.144 & 0.242 \\
C & -0.007 & 0.008 & -0.929 \\
CointnEq1 & $-0.056^{* *}$ & 0.027 & -2.238 \\
\hline
\end{tabular}

Note: Optimal lags are used based on SIC. 
Table 7. VAR Lag Order Selection Criteria

\begin{tabular}{llllll}
\hline Period & S.E. & LnCORR & LnRQ & LnVA & LnPS \\
\hline 1 & 0.087 & $100.000^{*}$ & 0.000 & 0.000 & 0.000 \\
2 & 0.122 & $97.636^{*}$ & 0.066 & $0.427^{*}$ & $1.871^{*}$ \\
3 & 0.146 & $96.107^{*}$ & 0.047 & $0.621^{*}$ & $3.225^{*}$ \\
4 & 9.165 & $95.025^{*}$ & 0.037 & $0.687^{*}$ & $4.251^{*}$ \\
5 & $94.107^{*}$ & 0.032 & $0.726^{*}$ & $5.136^{*}$ \\
6 & 0.182 & $93.290^{*}$ & 0.029 & $0.755^{*}$ & $5.926^{*}$ \\
7 & 0.197 & $92.563^{*}$ & 0.027 & $0.779^{*}$ & $6.631^{*}$ \\
8 & 0.211 & $91.918^{*}$ & 0.027 & $0.798^{*}$ & $7.258^{*}$ \\
9 & 0.223 & $91.344^{*}$ & 0.026 & $0.813^{*}$ & $7.816^{*}$ \\
\hline 10 & 0.236 & $90.835^{*}$ & 0.026 & $0.826^{*}$ & $8.312^{*}$ \\
\hline
\end{tabular}

and regulatory quality has a positive impact on corruption for the next year's periods. The results of FEVD demonstrate that shocks to corruption, and political stability are more important than regulatory quality, and voice and accountability, in both the short and long runs. In general, the estimated value of the relative importance for each variable is statistically significant. However, there is one exception: regulatory quality. It reflects the weakness of the relative contribution of the change in the regulatory quality in explaining the change in corruption. This means that there is a weakness in regulations and legislation in upholding the principle of equal opportunities. Therefore, there is a critical demand to address lows that preserve the rights of individuals and societies and combat corruption in the region.

The results also indicate that the ability of citizens to express their views and the accountability of the government and the stability of political environment may undermine corruption. Therefore, policies that promote political stability and the participation of citizens by expressing their views in the Arab government are expected to reduce corruption in those countries. In general, Arab governments should pay more attention to institutional and organizational reforms. In other words, the fight against corruption should be an integral part of a comprehensive institutional and organizational reform strategy. The results of this study will be an important incentive for Arab governments and global development organizations to improve the dimensions of good governance against corruption.

\section{References}

Ahmed, F. G., \& Asmaa, M. E. (2016). Growth and corruption in Arab countries: What type of relationship connects them? Journal of Economics and International Finance, 8(5), 44-55.

Aidt, T., Dutta, J., \& Sena, V. (2008). Governance regimes, corruption and growth: Theory 
and evidence. Journal of Comparative Economics, 36(2), 195-220.

Besançon, M. (2003). Good governance rankings. The art of Measurement. World Peace Foundation. WPF Reports, 36.

Blackburn, K., Bose, N., \& Haque, E. (2010). Endogenous corruption in economic development. Journal of Economic Studies, 37(1), 4-25.

Bluedorn, J. C. (2001). Can democracy help? Growth and ethnic divisions. Economics Letters, 70(1), 121-126.

Brunetti, A., \& Weder, B. (2003). A free press is bad news for corruption. Journal of Public economics, 87(7-8), 1801-1824.

Brunetti, A., Kisunko, G., \& Weder, B. (1998). Credibility of rules and economic growth: evidence from a worldwide survey of the private sector. World Bank Economic Review, 12, 353384.

Campos, N. F., \& Nugent, J. B. (2003). Aggregate investment and political instability: An econometric investigation. Economica, 70(279), 533-549.

Choi, N. (2007). Group composition and employee creative behaviour in a Korean electronics company: Distinct effects of relational demography and group diversity. Journal of Occupational and Organizational Psychology, 80, 213-234

Drebee, H., Azam, A., \& Razzaq, S. (2017). Impact of oil price fluctuations on economic growth, financial development and exchange rate: New evidence from Iraq. Proceedings of the 2nd International Conference on Economics, Education, Business and Accounting (The 2nd ICEEBA 2017) Makassar, Indonesia.

Dreher, A., \& Schneider, F. (2010). Corruption and the shadow economy: an empirical analysis. Public Choice, 144(1-2), 215-238.

Easterly, W., \& Levine, R. (1997). Africa's growth tragedy: Policies and ethnic divisions. Quarterly Journal of Economics, 112,1203-50.

Elliott, A. (1997). Corruption in the global economy. Washington, D. Institute for international Economics.

Gander, J. P. (2011). Microeconomics of corruption among developing economies. Economics, Management, and Financial Markets, 6(3), 11-22.

Gao, Y. (2011). Government intervention, perceived benefit, and bribery of firms in transitional China. Journal of Business Ethics, 104(2), 175-184.
Granger, J. (1969). Investigating causal relations by econometric models and cross-spectral methods. Econometrica, 37, 424-438.

Granger, J. (1986). Development in the study of cointegrated economic variables. Oxford Bulletin of Economics and Statistics, 48(3), 213-228.

Granger, J., \& Newbold, P. (1974). Spurious regression in econometrics. Journal of Econometrics, 2(2): 111-120.

Grindle, M. S. (2004). Good enough governance: poverty reduction and reform in developing countries. Governance, 17(4), 525-548.

Grindle, M. S. (2007). Good enough governance revisited. Development policy review, 25(5), 533 574.

Gyimah- Brempong, K. (2002). Corruption, economic growth, and income inequality in Africa. Economics of Governance, 3(3), 183-209.

Klitgaard, R. (1991). Controlling Corruption. University of California Press.

Knack, S., \& Azfar, O. (2003). Trade intensity, country size and corruption. Economics of governance, 4(1), 1-18.

Kaufmann, D., Kraay, A., \& Zoido-Lobaton, P. (1999). Governance matters. World Bank Policy Research Working Paper 2196.

Knack, S., \& Keefer, P. (1995). Institutions and economic performance: cross country tests using alternative institutional measures. Economics \& Politics, 7(3), 207-227

Kraay, A., \& Kaufmann, D. (2002). Growth without governance. The World Bank.

http://documents.worldbank.org/curated/ en/811781468766468180/Growth-withoutgovernance

Lambsdorff, G. (2006). The validity and precision of subjective indicators (CPI). In Sampford, C.J., Shacklock, A. H., Connors, C., \& F. Galtung (Eds.), Measuring Corruption (pp 81-99). Ashgate.

Lambsdorff, J. G. (1999). The Transparency International corruption perceptions index 1999: Framework document. Transparency International. https://images.transparencycdn. org/images/1999_CPI_Framework_EN.pdf.

Leite, M. C., \& Weidmann, J. (1999). Does mother nature corrupt: Natural resources, corruption, and economic growth. International Monetary Fund.

Mauro, P. (1995). Corruption and growth. Quarterly Journal of Economics, 110, 681-712.

Montalvo, J. G., \& Reynal-Querol, M. (2005). Ethnic diversity and economic development. Journal of Development economics, 76(2), 293-323. 
Nelson, R., \& Plosser, I. (1982). Trends and random walks in macroeconomic time series: Some evidence and implications. Journal of Monetary Economics, 10(2), 139-162.

Ngo, T. W. (2008). Rent-seeking and economic governance in the structural nexus of corruption in China. Crime, Law and Social Change, 49(1), 27-44.

Nurudeen, A., Abd Karim, M. Z., \& Aziz, M. I. (2015). Corruption, political instability and economic development in the Economic Community of West African States (ECOWAS): is there a causal relationship?. Contemporary economics, 9(1), 4560.

Pedroni, P. (1999). Critical values for co-integration tests in heterogeneous panels with multiple repressor's, Oxford Bulletin of Economics and Statistics, 61(1), 653-670.

Pedroni, P. (2004). Panel cointegration: asymptotic and finite sample properties of pooled time series tests with an application to the PPP hypothesis. Econometric theory, 20(3), 597-625.

Phillips, P. (1986). Understanding spurious regression in econometrics, Journal of Econometrics, 33(3), 311-340.

Poirson, M. H. (1998). Economic security, private investment, and growth in developing countries. International Monetary Fund.

Saeed Meo, M. (2017). Impact of political stability, government effectiveness and corruption on stock markets of South Asia. Journal of the Punjab University Historical Society, 30(1), 1-16.

Swaleheen, M. U. (2007). Corruption and investment choices: A panel data study. Kyklos, 60 (4), 601616.

Szeftel, M. (1998). Misunderstanding African politics: Corruption \& the governance agenda. Review of African political economy, 25(76), 221-240.

Tanzi, V. (1998). Corruption around the world: Causes, consequences, scope, and cures. Staff papers, 45(4), 559-594.

Tanzi, V., \& Davoodi, H. (1997). Corruption, public investment and growth. IMF Working Paper No.WP/97/139.

Treisman, D. (2000). Decentralization and inflation: Commitment, collective action, or continuity. American Political Science Review, 94(4), 837-857.

Transparency International (2017). Corruption Perception Index [Data set]. Available at: http://www.transparency.org/research/cpi/ overview.
Touati, K. (2014). Determinants of economic corruption in the Arab countries: Dangers and remedies. Journal of Economics Studies and Research, 2014(1), 1-15.

Wagner, F. \& Schneider, F. (2005). Satisfaction not guaranteed - Institutions of conflict management and satisfaction with democracy in Western Europe. Center for Economic studies and ifo Institute Working Paper, 910. https://www. econstor.eu/bitstream/10419/76271/1/cesifo_ wp910.pdf

Weiss, T. G. (2000). Governance, good governance and global governance: conceptual and actual challenges. Third world quarterly, 21(5), 795-814.

Wheeler, M. (1999). The macroeconomic impacts of government debt: An empirical analysis of the 1980s and 1990s. Atlantic Economic Journal, 27(3), 273-284.

World Bank (2009, June 29). Governance matters 2009: Release of worldwide governance Indicators 19962016.[Press release]. http://www.worldbank.org/ en/news/press-release/2009/06/29/governancematters-2009-release-of-worldwide-governanceindicators-1996-2008.

World Bank (2017). World Development Indicators [Data set]. http://data.worldbank.org. 